\title{
A retrospective comparative study of prednisolone use in antagonist co-treated assisted reproductive technology cycles for patients with good prognosis
}

\author{
Yardımci üreme teknikleri ile tedavi edilecek iyi prognozlu \\ hastaların antagonist sikluslarında prednizolon kullanımı \\ retrospektif karşılaştırma
}

\author{
(1) Batuhan Özmen ${ }^{1}$, (1) Emre Göksan Pabuçcu ${ }^{2}$, (1) Yavuz Emre Şükür ${ }^{1}$, (1) Hasan Ulubaşoğlu ${ }^{3}$, (1) Can Ateş ${ }^{4}$, \\ (D) Murat Sönmezer ${ }^{1}$, (1) Bülent Berker ${ }^{1}$, (1) Cem Somer Atabekoğlu ${ }^{1}$
}

${ }^{1}$ Ankara University Faculty of Medicine, Department of Obstetrics and Gynecology, Ankara, Turkey

${ }^{2}$ Ufuk University Faculty of Medicine, Department of Obstetrics and Gynecology, Ankara, Turkey

${ }^{3}$ Ondokuz Mayis University Faculty of Medicine, Department of Obstetrics and Gynecology, Samsun, Turkey

${ }^{4}$ Ankara University Faculty of Medicine, Department of Biostatistics, Ankara, Turkey

\begin{abstract}
Objective: To investigate the impact of peri-implantation prednisolone use and its duration in antagonist co-treated assisted reproductive technology (ART) cycles of patients with good prognosis.

Materials and Methods: Infertile patients treated with gonadotropin-releasing hormone antagonist protocol between January 2010 and June 2013 were included. The patients in group A ( $\mathrm{n}=196)$ received no prednisolone. The patients in groups $\mathrm{B}(\mathrm{n}=397)$ and $\mathrm{C}(\mathrm{n}=371)$ received 5 mg oral prednisolone daily, for 4 and 12 days following embryo transfer, respectively. The main outcome parameter was live birth rate.

Results: The ages of the groups were $30.1 \pm 4.6,31.5 \pm 4.5$, and $30.9 \pm 4.7$ years, respectively $(\mathrm{p}=0.163)$. There was no statistically significant difference between the groups regarding cycle characteristics. Implantation rates were $20.7 \%, 24.6 \%$, and $23.8 \%$, respectively ( $\mathrm{p}=0.163$ ). Miscarriage rates were $1.5 \%, 3.5 \%$, and $3.2 \%$, respectively ( $\mathrm{p}=0.859)$. Live birth rates were $28.7 \%, 29.3 \%$, and $32.8 \%$, respectively $(\mathrm{p}=0.482)$.

Conclusion: Empiric prednisolone administration during the peri-implantation period does not seem to have beneficial effects in ART cycles of patients with good prognosis.
\end{abstract}

Keywords: Assisted reproductive technology, glucocorticoid, gonadotropin-releasing hormone antagonist, peri-implantation period

$\ddot{\mathrm{O} z}$

Amaç: Yardımcı üreme teknikleri (YÜT) ile tedavi edilecek iyi prognozlu hastaların antagonist sikluslarında peri-implantasyon döneminde prednizolon kullanımının etkisinin araştırılması.

Gereç ve Yöntemler: Ocak 2010 ile Haziran 2013 arasında gonadotropin releasing hormon antagonist protoklü ile tedavi edilen infertil hastalar dahil edilmiştir. A grubundaki hastalar $(n=196)$ prednizolon kullanmamıştır. B grubundaki $(n=397)$ ve C grubundaki $(n=371)$ hastalar embriyo transferini takiben sırasıyla 4 gün ve 12 gün 5 mg oral prednizolon kullanmıştır. Ana sonuç parametresi canlı doğum oranıdır.

Bulgular: Grupların yaş ortalamaları sırasıyla $30,1 \pm 4,6,31,5 \pm 4,5$ ve $30,9 \pm 4,7$ ylldı $(p=0,163)$. Siklus özellikleri açısından gruplar arasında istatistiksel olarak anlamlı fark yoktu. Düşük oranları sırasıyla \%1,5, \%3,5, ve \%3,2 olarak bulundu ( $\mathrm{p}=0,859)$. Canlı doğum oranları sirasıyla \%28,7, \%29,3 ve \%32,8 olarak bulundu ( $\mathrm{p}=0,482)$.

Sonuç: İyi prognozlu hastaların YÜT sikluslarında peri-implantasyon döneminde ampirik prednizolon kullanımının olumlu etkisi yoktur.

Anahtar Kelimeler: Yardımcı üreme teknikleri, glukokortikoid, gonadotropin releasing hormon antagonisti, peri-implantasyon dönemi

PRECIS: In the present study, we evaluated peri-implantation prednisolone use and its duration in a large cohort of patients undergoing assisted reproductive technology with good prognosis.

Address for Correspondence/Yazıșma Adresi: Yavuz Emre Şükür, MD,

Ankara University Faculty of Medicine, Department of Obstetrics and Gynecology, Ankara, Turkey

Phone: +90 5332409381 E-mail: yesukur@yahoo.com ORCID ID: orcid.org/0000-0003-0815-3522

Received/Geliș Tarihi: 07.04.2018 Accepted/Kabul Tarihi: 26.04.2018

${ }^{\oplus}$ Copyright 2018 by Turkish Society of Obstetrics and Gynecology

Turkish Journal of Obstetrics and Gynecology published by Galenos Publishing House. 


\section{Introduction}

The implantation process of the embryo is a consequence of complex molecular interactions involving many cytokines, growth factors, and immune cells ${ }^{(1,2)}$. In this regard, several molecules have been suggested to improve implantation and contribute to successful pregnancy when administered during the peri-implantation period. Glucocorticoids, well-known agents with anti-inflammatory and immune suppressive properties, have been investigated for the last few decades and conflicting data have been published ${ }^{(3-8)}$. Some authors advocate the beneficial effect in zona-dissected embryos and in the presence of assisted-hatching, whereas others reported significantly higher pregnancies in women with auto-antibodies after the use of glucocorticoids ${ }^{(6,9-11)}$. On the contrary, several researchers reported no significant beneficial effect of peri-implantation glucocorticoid administration on implantation and clinical pregnancy rates in intracytoplasmic sperm injection (ICSI) cycles $^{(12,13)}$. Published evidence is too limited and heterogeneous to support any firm conclusion on the value of preimplantation prednisolone use in assisted reproductive technology (ART) for patients considered to have good prognosis. In the present study, we aimed to investigate the impact of peri-implantation prednisolone use and its duration in antagonist co-treated ART cycles of patients with good prognosis.

\section{Materials and Methods}

Infertile patients treated with gonadotropin-releasing hormone (GnRH) antagonist co-treated ART in the Infertility Centre of Ankara University Faculty of Medicine, Turkey, between January 2010 and June 2013 were included in this retrospective cohort study. The clinic where the present study was conducted belongs to a tertiary referral hospital that mainly serves the central and east side of the country with approximately 1000 ART cycles per year. The Institutional Review Board of Ankara University Faculty of Medicine approved the study (approval number: 08-341-16). The first stimulation cycle for each subject was included in the study to prevent possible crossover bias between the groups. The inclusion criteria were being female, age $18-40$ years, baseline follicle-stimulating hormone (FSH) level $<15$ IU/L, diagnosed as tubal factor or unexplained infertility, ICSI treatment, and with complete birth data. The exclusion criteria were body mass index (BMI) $>30 \mathrm{~kg} / \mathrm{m}^{2}$, presence of any untreated thyroid dysfunction/hyperprolactinemia, diminished ovarian reserve according to the Bologna criteria $^{(14)}$ or premature ovarian failure, uterine abnormality, positive tests for antinuclear, anti-double-stranded DNA, anticardiolipin antibodies or lupus anticoagulant, male factor infertility, endometriosis, frozen-thaw cycles, cycles managed with assisted hatching, and cycles with day 5 embryo transfer (ET). Cycle cancellations were performed due to a lack of ovarian response or fertilization failure. For eligible participants, we extracted all data regarding controlled ovarian stimulation (COS) and clinical outcomes from the database, and divided the patients into three groups according to their prednisolone administration protocol. Group A received no prednisolone. Groups $B$ and $C$ received $5 \mathrm{mg}$ oral prednisolone daily for 4 and 12 days following ET, respectively. The different prednisolone protocols were due to the primary physician's choice. Ovarian stimulation was performed with recombinant FSH (Gonal-F, Merck-Serono, İstanbul, Turkey) beginning from the second day of the menstrual cycle with a fixed starting dosage of $150 \mathrm{IU} /$ day. Dose adjustment was performed individually according to ovarian response. The GnRH antagonist (Cetrotide, Merck-Serono, İstanbul, Turkey) was introduced $(0.25 \mathrm{mg} /$ day) on the sixth day (fixed antagonist protocol) and continued throughout ovarian stimulation. When at least three follicles were $\geq 18 \mathrm{~mm}$, recombinant human chorionic gonadotropin (hCG) $250 \mu \mathrm{g}$ (Ovitrelle, Merck-Serono, İstanbul, Turkey) was used for final oocyte maturation. Transvaginal ultrasonography-guided oocyte pick-up (OPU) was performed 35-36 hours after the hCG trigger. ET was performed on the $3^{\text {rd }}$ day of OPU. A maximum of two embryos were transferred under ultrasound guidance due to national ET regulations ${ }^{(15)}$. Embryos on the $2^{\text {nd }}$ and $3^{\text {rd }}$ days were classified as cleavage stage embryos and were graded based on cell numbers and the degree of fragmentation. All women were administered luteal phase support through $90 \mathrm{mg} /$ day vaginal micronized progesterone (Crinone $8 \%$ gel; MerckSerono, İstanbul, Turkey) commenced on OPU day. In the event of pregnancy, luteal phase support was continued until 10 weeks of gestation. Pregnancy and clinical pregnancy were defined, respectively, by measuring serum $\beta$-hCG levels 2 weeks after ET and as the presence of heartbeat at 6-7 weeks of gestation. The implantation rate was calculated separately for each woman as the number of gestational sacs divided by the number of transferred embryos multiplied by 100. The primary outcome measure was live birth rate (LBR).

\section{Statistical Analysis}

The Statistical Package for the Social Sciences (SPSS Inc., Chicago, IL, United States) 15.0 for Windows software was used for all statistical analyses. The Shapiro-Wilk test was used to test normal distribution of continuous parameters. When distribution of a continuous variable was normal, parametric tests were preferred. Continuous variables were compared using the One-Way ANOVA test. Categorical variables were compared using the chi-square test. Continuous data where descriptive tests used are presented as mean \pm standard deviation and categorical data are presented as frequency (percentage). A $p$ value of $<0.05$ was considered statistically significant. While planning the present study, we were not able to detect any previous studies investigating the effect of peri-implantation period use of prednisolone and its dosage 
in ART cycles of patients with good prognosis. Hypothetically, when a power analysis was performed with $80 \%$ power and an $\alpha$ value of 0.05 for an approximately $5 \%$ difference in LBR per cycle, the patient number for each study arm should be 1328 for the confirmation of statistical significance. Thus, in the present study, type 2 statistical error could not be excluded for this parameter. Considering the difficulty of recruiting so many participants to a single-centre trial, the aim was to finish the current trial using the data of the available cohort such that it could be included in future meta-analyses on the issue.

\section{Results}

During the study period, a total of 2970 ART cycles were performed in our unit. Among those, 1226 were first ART cycles of tubal factor or unexplained infertility patients, among whom 78 (6.3\%) patients with BMI $>30 \mathrm{~kg} / \mathrm{m}^{2}$ and 184 (15\%) patients with frozen-thawed or day 5 ET were excluded. As a result, the data of 964 first ART cycles of patients with good prognosis were found eligible for assessment.

The demographic characteristics of the study and control groups are presented in Table 1 and the cycle characteristics of the groups are presented in Table 2 . The outcome measures of the study are presented in Table 3. There were no statistically significant differences between the groups regarding clinical pregnancy, ongoing pregnancy, and LBRs.

\section{Discussion}

The aim of the present study was to investigate the impact of peri-implantation prednisolone use and its duration in antagonist co-treated ART cycles of patients with good prognosis. We found no significant impact of prednisolone administration during the peri-implantation period and its duration on implantation and clinical pregnancy rates and LBR in antagonist co-treated ART cycles of patients with good prognosis. To the best of our knowledge, this analysis is the largest evaluation of the effect of peri-implantation prednisolone use in antagonist co-treated cycles, and is the only comparison of two different doses of prednisolone. Immune suppressive properties of glucocorticoids have been questioned in terms of enhancing outcomes when administered during peri-implantation period because several factors are effective on implantation process. Although several studies and meta-analyses reported beneficial effects on pregnancy rates, those studies included patients with recurrent miscarriages ${ }^{(16-18)}$. However, in our

Table 1. Demographic characteristics of the study groups

\begin{tabular}{|c|c|c|c|c|}
\hline & Group A (n=196) & Group B $(\mathrm{n}=397)$ & Group C $(\mathrm{n}=371)$ & $\mathrm{p}$ \\
\hline Age $\left(\right.$ years) ${ }^{a}$ & $30.1 \pm 4.6$ & $31.5 \pm 4.5$ & $30.9 \pm 4.7$ & 0.065 \\
\hline Duration of infertility (years) ${ }^{\mathrm{a}}$ & $6.2 \pm 1.6$ & $6.8 \pm 3.9$ & $7.0 \pm 3.8$ & 0.253 \\
\hline Basal Estradiol $(\mathrm{pg} / \mathrm{mL})^{\mathrm{a}}$ & $46.7 \pm 35.9$ & $51.9 \pm 33.7$ & $48.5 \pm 26.3$ & $0.020^{\mathrm{b}}$ \\
\hline
\end{tabular}

Table 2. Cycle characteristics of the study groups

\begin{tabular}{|c|c|c|c|c|}
\hline & Group A (n=196) & Group B $(n=397)$ & Group C $(n=371)$ & $\mathrm{p}$ \\
\hline Duration of stimulation (days) ${ }^{a}$ & $10.4 \pm 3.6$ & $10.4 \pm 2.3$ & $10.8 \pm 2.1$ & 0.051 \\
\hline Total dose of gonadotropins (IU) ${ }^{\mathrm{a}}$ & $2338 \pm 868$ & $2471 \pm 827$ & $2350 \pm 787$ & 0.067 \\
\hline $\operatorname{Max} E_{2}(p g / m L)^{a}$ & $2306 \pm 1179$ & $2001 \pm 1204$ & $1829 \pm 1137$ & $<0.001^{\mathrm{b}}$ \\
\hline Retrieved oocytes (n) ${ }^{a}$ & $9.0 \pm 5.7$ & $8.8 \pm 6.1$ & $8.4 \pm 5.2$ & 0.492 \\
\hline MII oocytes $(n)^{a}$ & $6.8 \pm 4.5$ & $6.8 \pm 5.2$ & $6.8 \pm 4.6$ & 0.996 \\
\hline Fertilization rate $(\%)^{\mathrm{a}}$ & $67.4 \pm 29.3$ & $62.6 \pm 28.7$ & $63.7 \pm 32.6$ & 0.051 \\
\hline Endometrial thickness on day of OPU $(\mathrm{mm})^{\mathrm{a}}$ & $10.5 \pm 1.7$ & $10.2 \pm 1.5$ & $10.1 \pm 2.4$ & 0.058 \\
\hline No of transferred embryos $(n)^{\mathrm{a}}$ & $1.5 \pm 0.7$ & $1.5 \pm 0.8$ & $1.5 \pm 0.8$ & 0.522 \\
\hline Implantation rate $(\%)^{\mathrm{a}}$ & $20.7 \pm 35$ & $24.6 \pm 35.6$ & $23.8 \pm 33$ & 0.163 \\
\hline
\end{tabular}


Table 3. Comparison of outcome measures

\begin{tabular}{|c|c|c|c|c|}
\hline & Group A (n=196) & Group B $(n=397)$ & Group C $(n=371)$ & $\mathrm{p}$ \\
\hline Clinical pregnancy, n (\%) & $59(33.1 \%)$ & $135(34.0 \%)$ & $144(39.2 \%)$ & 0.263 \\
\hline Ongoing pregnancy, n (\%) & $56(31.5 \%)$ & $121(30.6 \%)$ & $132(35.7 \%)$ & 0.292 \\
\hline Live birth, $\mathrm{n}(\%)^{\mathrm{a}}$ & $51(28.7 \%)$ & $116(29.3 \%)$ & $120(32.8 \%)$ & 0.482 \\
\hline Miscarriage, $\mathrm{n}(\%)^{\mathrm{a}}$ & $3(1.5 \%)$ & $14(3.5 \%)$ & $12(3.2 \%)$ & 0.859 \\
\hline Cycle cancellation, $\mathrm{n}(\%)^{\mathrm{a}}$ & $16(8.2 \%)$ & $25(6.4 \%)$ & $20(5.6 \%)$ & 0.487 \\
\hline
\end{tabular}

study, we investigated the effect of prednisolone on patients with good prognosis. In the meta-analysis by Boomsma et al. ${ }^{(7)}$ including 14 RCTs and 1879 couples, the empiric use of prednisolone during the peri-implantation period was assessed and a borderline statistically significant increase in pregnancy rates was reported in in vitro fertilization but not in ICSI cycles, suggesting its limited use in ICSI cycles. Despite these results, the authors made their conclusions with caution because the included trials in which ICSI was used were very few and clinically heterogeneous. However, in our study, we included only first ICSI cycles of patients with good prognosis to obtain a relatively homogenous cohort. In the present study, we investigated prednisolone $5 \mathrm{mg}$ because lower doses have already been reported to reveal similar immune-suppression and pregnancy outcomes when compared with higher doses ${ }^{(12,19,20)}$. According to the results of our study, short and long-term use of prednisolone has a similar effect on implantation and pregnancy rates. Additionally, only antagonist co-treated cycles were included because this protocol has widely replaced GnRH agonist cycles globally with its applicability and non-inferior outcomes. The implantation and pregnancy rates were consistent with rates in the available literature, especially with those of Ubaldi et al. ${ }^{(12)}$ who also included patients with good prognosis and used low-dose glucocorticoid. The large number of subjects included in the analyses and the strict inclusion criteria of those with good prognosis were the main strengths of our study. The available LBR data might be of some interest. Moreover, we assessed the impact of prednisolone duration, comparing short and prolonged use. According to the results, neither short nor long-course peri-implantation-period prednisolone administration has any benefit in antagonist cotreated ART cycles of patients with good prognosis. Hence, prednisolone should not be prescribed for routine ART cycles. The results of our study may be used in future metaanalyses investigating prednisolone administration in ART cycles of patients with good prognosis. Large randomized clinical trials may be more suggestive on prednisolone use in patients undergoing ICSI with good prognosis.

The retrospective nature and lack of randomization are the main limitations of the present study. Another limitation is the different manipulations during the COS protocols, mainly dose adjustment and duration of prednisolone treatment, due to primary physician preferences, which could affect the outcome. Moreover, the low power of the statistical analysis can be noted as a limitation. However, given the select nature of our population, attaining such a large cohort was unrealistic in a single-centre study.

\section{Conclusion}

In the present study we could not find an unequivocal beneficial effect of empiric prednisolone administration during the peri-implantation period in women undergoing their first ART cycle with an antagonist protocol. According to the results of our study, within the context of its limitations, a complete shift in clinical practice cannot be suggested.

\section{Ethics}

Ethics Committee Approval: The study was approved by the Ankara University Local Ethics Committee (approval number: 08-341-16).

Informed Consent: Not applicable.

Peer-review: Internally peer-reviewed.

\section{Authorship Contributions}

Surgical and Medical Practices: B.Ö., M.S., B.B., C.S.A., Concept: B.Ö., E.G.P., Design: B.Ö., Y.E.Ş., Data Collection or Processing: H.U., E.G.P., Analysis or Interpretation: C.S.A., B.Ö., Y.E.Ş., Literature Search: Y.E.Ş., H.U., E.G.P., Writing: Y.E.Ş., H.U., E.G.P., B.Ö.

Conflict of Interest: No conflict of interest was declared by the authors.

Financial Disclosure: The authors declared that this study received no financial support.

\section{References}

1. Dey SK, Lim H, Das SK, Reese J, Paria BC, Daikoku T, et al. Molecular cues to implantation. Endocr Rev 2004;25:341-73.

2. Ledee-Bataille N, Bonnet-Chea K, Hosny G, Dubanchet S, Frydman $\mathrm{R}$, Chaouat G. Role of the endometrial tripod interleukin-18, -15, and -12 in inadequate uterine receptivity in patients with a history of repeated in vitro fertilization-embryo transfer failure. Fertil Steril 2005;83:598-605

3. Polak de Fried E, Blanco L, Lancuba S, Asch RH. Improvement of clinical pregnancy rate and implantation rate of in-vitro fertilizationembryo transfer patients by using methylprednisone. Hum Reprod 1993;8:393-5. 
4. Moffitt D, Queenan JT Jr, Veeck LL, Schoolcraft W, Miller CE, Muasher SJ. Low-dose glucocorticoids after in vitro fertilization and embryo transfer have no significant effect on pregnancy rate. Fertil Steril 1995;63:571-7.

5. Bider D, Menashe Y, Goldenberg M, Dulitzky M, Lifshitz A, Dor J. Dexamethasone as an adjuvant therapy for anovulatory, normoandrogenic patients during ovulation induction with exogenous gonadotropins. J Assist Reprod Genet 1996;13:613-6.

6. Primi MP, Senn A, Montag M, Van der Ven H, Mandelbaum J, Veiga A, et al. A European multicentre prospective randomized study to assess the use of assisted hatching with a diode laser and the benefit of an immunosuppressive/antibiotic treatment in different patient populations. Hum Reprod 2004;19:2325-33.

7. Boomsma CM, Keay SD, Macklon NS. Peri-implantation glucocorticoid administration for assisted reproductive technology cycles. Cochrane Database Syst Rev 2012;6:CD005996.

8. Nyborg KM, Kolte AM, Larsen EC, Christiansen OB. Immunomodulatory treatment with intravenous immunoglobulin and prednisone in patients with recurrent miscarriage and implantation failure after in vitro fertilization/intracytoplasmic sperm injection. Fertil Steril 2014;102:1650-5.

9. Cohen J, Elser C, Kort H, Malter H, Massey J, Mayer MP, et al. Impairment of the hatching process following IVF in the human and improvement of implantation by assisted hatching using micromanipulation. Hum Reprod 1990;5:7-13.

10. Cohen J, Malter H, Elsner C, Kort H, Massey J, Mayer MP. Immunosuppression supports implantation of zona pellucida dissected human embryos. Fertil Steril 1990;53:662-5.

11. Ando T, Suganuma N, Furuhashi M, Asada Y, Kondo I, Tomoda Y. Successful glucocorticoid treatment for patients with abnormal autoimmunity on in vitro fertilization and embryo transfer. J Assist Reprod Genet 1996;13:776-81.

12. Ubaldi F, Rienzi L, Ferrero S, Anniballo R, Iacobelli M, Cobellis L, et al. Low dose prednisolone administration in routine ICSI patients does not improve pregnancy and implantation rates. Hum Reprod 2002;17:1544-7.
13. Duvan CI, Ozmen B, Satiroglu H, Atabekoglu CS, Berker B. Does addition of low-dose aspirin and/or steroid as a standard treatment in nonselected intracytoplasmic sperm injection cycles improve in vitro fertilization success? A randomized, prospective, placebocontrolled study. J Assist Reprod Genet 2006;23:15-21.

14. Ferraretti P, La Marca A, Fauser BC, Tarlatzis B, Nargund G, Gianaroli L, et al. ESHRE consensus on the definition of 'poor response' to ovarian stimulation for in vitro fertilization: the Bologna criteria. Hum Reprod 2011;26:1616-24.

15. Resmi Gazete. Üremeye yardımcı tedavi uygulamaları ve üremeye yardımcı tedavi merkezleri hakkında yönetmelik. Resmi Gazete 2010; 06 Mart, No: 27513. http://www.resmigazete.gov.tr/ eskiler/2010/03/20100306-10.htm

16. Tang AW, Alfirevic Z, Turner MA, Drury JA, Small R, Quenby S. A feasibility trial of screening women with idiopathic recurrent miscarriage for high uterine natural killer cell density and randomizing to prednisolone or placebo when pregnant. Hum Reprod 2013;28:1743-52.

17. Gomaa MF, Elkholy AG, El-Said MM, Abdel-Salam NE. Combined oral prednisolone and heparin versus heparin: the effect on peripheral NK cells and clinical outcome in patients with unexplained recurrent miscarriage. A double-blind placebo randomized controlled trial. Arch Gynecol Obstet 2014;290:757-62.

18. Dan S, Wei W, Yichao S, Hongbo C, Shenmin Y, Jiaxiong W, et al. Effect of prednisolone administration on patients with unexplained recurrent miscarriage and in routine intracytoplasmic sperm injection: a meta-analysis. Am J Reprod Immunol 2015;74:89-97.

19. Claman HN. Glucocorticosteroids I: anti-inflammatory mechanisms. Hospital Pract (Off Ed) 1983;18:123-6.

20. Lee KA, Koo JJ, Yoon TK, Do BR, Ko JJ, Cha KY. Immunosuppression by glucocorticoid has no effect on the pregnancy rate in routine in-vitro fertilization/embryo transfer patients. Hum Reprod 1994;9:1832-5. 